\title{
Acute myocarditis Role of histological and virological examination in the diagnosis and assessment of immunosuppressive treatment
}

\author{
K DALY, P J RICHARDSON, E G J OLSEN, P MORGAN-CAPNER, CLAIRE MCSORLEY, \\ G JACKSON, D E JEWITT
}

From the Departments of Cardiology and Microbiology, King's College Hospital, and Department of Histopathology, National Heart Hospital, London

SUMMARY Twelve patients, who presented with congestive cardiac failure after a recent influenza like illness, had a clinical diagnosis of acute myocarditis confirmed histologically after endomyocardial biopsy. Eight were under 30 years of age. Serological testing suggested a viral aetiology in six patients.

Nine patients were treated with immunosuppressive drugs (prednisolone and azathioprine in seven, prednisolone alone in two). At two months, seven patients showed clinical and haemodynamic improvement (ejection fraction rose from 26.8 to $49 \%$ and left ventricular end diastolic pressure fell from 26.4 to $16.2 \mathrm{~mm} \mathrm{Hg}$ ) with biopsy evidence of healed myocarditis. In two, activity persisted. At six months' follow up only four of these patients had maintained their improvement. One patient relapsed after stopping treatment, subsequently improving on its reinstatement. Two patients developed severe interstitial myocardial fibrosis with gradual deterioration.

Virology and myocardial histology were complementary in the diagnosis of acute myocarditis in these young patients, whose response to immunosuppressive treatment was variable. An apparent early response could not be clearly separated from variables in the natural history of the condition. Serial endomyocardial biopsies showed a progression to congestive cardiomyopathy in two patients. Multicentre controlled trials will be necessary to assess fully the role of immunosuppressive treatment in this condition.

The clinical diagnosis of myocarditis is suggested by a preceding viral illness, electrocardiographic changes, changes in heart size on $x$ ray examination, and a supportive rise in viral titres. ${ }^{1}$ Until the advent of endomyocardial biopsy, however, it was not possible to obtain histological confirmation of myocarditis in the acute phase and to study the response of the heart muscle to treatment. ${ }^{2}$

The present study reports a 16 month experience of the investigation of 12 patients, presenting with an acute onset of cardiac failure, in whom the diagnosis of myocarditis was confirmed by endomyocardial biopsy. Detailed virological studies were performed to assess the relation of the myocarditis to viral infection. Nine of the 12 patients were treated with

This work was supported by a British Heart Foundation grant. The research facilities provided in the Rayne Institute and by King's College Hospital Voluntary Research Trust are gratefully acknowledged.

Accepted for publication 17 August 1983 immunosuppressive drugs for at least six months, and the results of treatment were assessed by serial haemodynamic, angiographic, and biopsy studies.

\section{Patients and methods}

Fifteen patients with a suspected diagnosis of acute viral myocarditis underwent investigation at King's College Hospital over a 16 month period from April 1980 to June 1981. These represent a substantial proportion (21.7\%) of the 69 patients who were investigated for all forms of heart muscle disease over the same period. Myocarditis was confirmed on histological examination in 12 patients either at presentation (11 patients) or on follow up (one patient), and these 12 patients formed the basis of the present study. The nine females and three males, with an average age of 28.5 years (range 15 to 46 years), presented with congestive cardiac failure one to 16 weeks (average 11 
weeks) after an acute viral like illness. All patients were in New York Heart Association class III or IV (Table). ${ }^{3}$ None had a preceding history of heart disease.

Preliminary investigations included chest $x$ ray examination, electrocardiography, echocardiography, and cardiac catheterisation with selective coronary arteriography and ventriculography. The results of these investigations were consistent with a diagnosis of dilated cardiomyopathy. In the absence of valvar, coronary, or hypertensive heart disease, endomyocardial biopsy and virological investigations were performed.

\section{ENDOMYOCARDIAL BIOPSY}

Left ventricular endomyocardial tissue was obtained (average three biopsies per patient) using the King's endomyocardial bioptome 4 and the percutaneous long sheath technique. The tissue samples were prepared for histological and electron microscopical analysis as previously described. 5 A further biopsy sample was taken for virus culture and immunofluorescent staining for Coxsackie B antigens.

\section{HISTOPATHOLOGICAL EVALUATION}

Diagnostic criteria for acute myocarditis included an appreciable lymphocytic and inflammatory cell infiltrate and myocyte necrosis with fraying of adjacent myocardial fibres (Fig.1). Additional features such as widening of the interstitium and myocardial fibrosis were also noted. A diagnosis of "healed myocarditis" was made if the subsequent biopsies no longer showed myocyte necrosis and the inflammatory infiltrate had diminished.

\section{VIROLOGICAL STUDIES}

Virological studies consisted of stool and throat swab cultures and serological screening for a wide variety of viruses. This included the determination of Coxsackie $B_{1-5}$ neutralising antibody titres and the detection of Coxsackie $B_{1-2}$ specific IgM by sucrose density gradient fractionation of the serum, with neutralising titres being performed on the fractions obtained. ${ }^{6}$ The myocardial biopsy specimens were cultured for Coxsackie virus and stained for Coxsackie $B_{1-5}$ specific immunofluorescence.

\section{TREATMENT PROTOCOL}

Immunosuppressive treatment consisted of oral prednisolone and azathioprine both in a dose of 50 $\mathrm{mg} / \mathrm{m}^{2} /$ day. After two weeks the dose of prednisolone was reduced to $10 \mathrm{mg} / \mathrm{m}^{2} /$ day, and after two months' treatment the patients were readmitted for full investigations, including repeat endomyocardial biopsy. Immunosuppressive treatment was continued for six months. The patients were reinvestigated one month after withdrawal of treatment, and if clinical and histological recovery persisted no further immunosuppression was given.

\section{STATISTICAL ANALYSIS}

Where appropriate, statistical analysis of the results was performed using Student's paired $t$ test.

\section{Results}

\section{FINDINGS AT DIAGNOSIS}

Virology

Serological testing indicated a viral cause in six

Table Details of histology, virology, and treatment in 12 patients with acute myocarditis

\begin{tabular}{|c|c|c|c|c|c|c|c|c|}
\hline \multirow[b]{2}{*}{ Patient No } & \multirow[b]{2}{*}{ Age (year) } & \multirow[b]{2}{*}{ Sex } & \multirow[b]{2}{*}{ NYHA Class } & \multicolumn{2}{|c|}{ Myocardial histology } & \multirow[b]{2}{*}{ Virus serology } & \multirow[b]{2}{*}{ Biopsy culture } & \multirow[b]{2}{*}{$\begin{array}{l}\text { Immunosuppressive } \\
\text { treatment }\end{array}$} \\
\hline & & & & Myocarditis & $\begin{array}{l}\text { Interstitial } \\
\text { fibrosis }\end{array}$ & & & \\
\hline 1 & 24 & $\mathbf{F}$ & IV & Active & - & $\begin{array}{l}\text { Herpes simplex } \\
\text { CFT } 16 \text { to } 256\end{array}$ & Negative & $\mathbf{P}+\mathbf{A}$ \\
\hline $\begin{array}{l}2 \\
3\end{array}$ & $\begin{array}{l}28 \\
41\end{array}$ & $\begin{array}{l}\mathbf{F} \\
\mathbf{M}\end{array}$ & $\begin{array}{l}\text { III } \\
\text { III }\end{array}$ & $\begin{array}{l}\text { Active } \\
\text { Active }\end{array}$ & - & $\begin{array}{c}- \\
\text { Coxsackie B4 } \\
\text { NAT } 1280\end{array}$ & $\begin{array}{l}\text { Negative } \\
\text { Negative }\end{array}$ & $\begin{array}{l}\mathbf{P}+\mathbf{A} \\
-\end{array}$ \\
\hline 4 & 15 & $\mathbf{F}$ & IV & Active & - & $\begin{array}{l}\text { Coxsackie B3 } \\
\text { NAT } 640\end{array}$ & Negative & $\mathbf{P}+\mathbf{A}$ \\
\hline 5 & 46 & $\mathbf{M}$ & IV & Active & - & $\begin{array}{l}\text { Coxsackie B4 } \\
\text { NAT } 320 \\
\text { IgM + }\end{array}$ & Negative & - \\
\hline 6 & 46 & $\mathbf{F}$ & IV & Active & + & $\begin{array}{l}\text { Coxsackie B4 } \\
\text { NAT } 320 \\
\text { IgM + }\end{array}$ & Negative & $\mathbf{P}$ \\
\hline $\begin{array}{r}7 \\
8 \\
9 \\
10 \\
11 \\
12\end{array}$ & $\begin{array}{l}17 \\
27 \\
20 \\
34 \\
22 \\
28\end{array}$ & $\begin{array}{l}\mathbf{M} \\
\mathbf{F} \\
\mathbf{F} \\
\mathbf{F} \\
\mathbf{F} \\
\mathbf{F}\end{array}$ & $\begin{array}{l}\text { IV } \\
\text { IV } \\
\text { IV } \\
\text { III } \\
\text { III } \\
\text { III }\end{array}$ & $\begin{array}{l}\text { Active } \\
\text { Active } \\
\text { Active } \\
\text { Active } \\
\text { Active } \\
-\end{array}$ & $\begin{array}{l}\overline{++} \\
= \\
=\end{array}$ & $\begin{array}{l}\overline{-} \\
\overline{-} \\
\overline{\text { Coxsackie B4 }} \\
\text { NAT } 640\end{array}$ & $\begin{array}{l}\text { Negative } \\
\text { Negative } \\
\text { Negative } \\
\text { Negative } \\
\text { Negative } \\
\text { Negative }\end{array}$ & $\begin{array}{l}\mathbf{P}+\mathbf{A} \\
\mathbf{P}+\mathbf{A} \\
\mathbf{P}+\mathbf{A} \\
\mathbf{P}+\mathbf{A} \\
\mathbf{P}+\mathbf{A} \\
-\end{array}$ \\
\hline
\end{tabular}

P, prednisolone; A, azathioprine; NAT, neutralising antibody titre; CFT, complement fixation titre. 


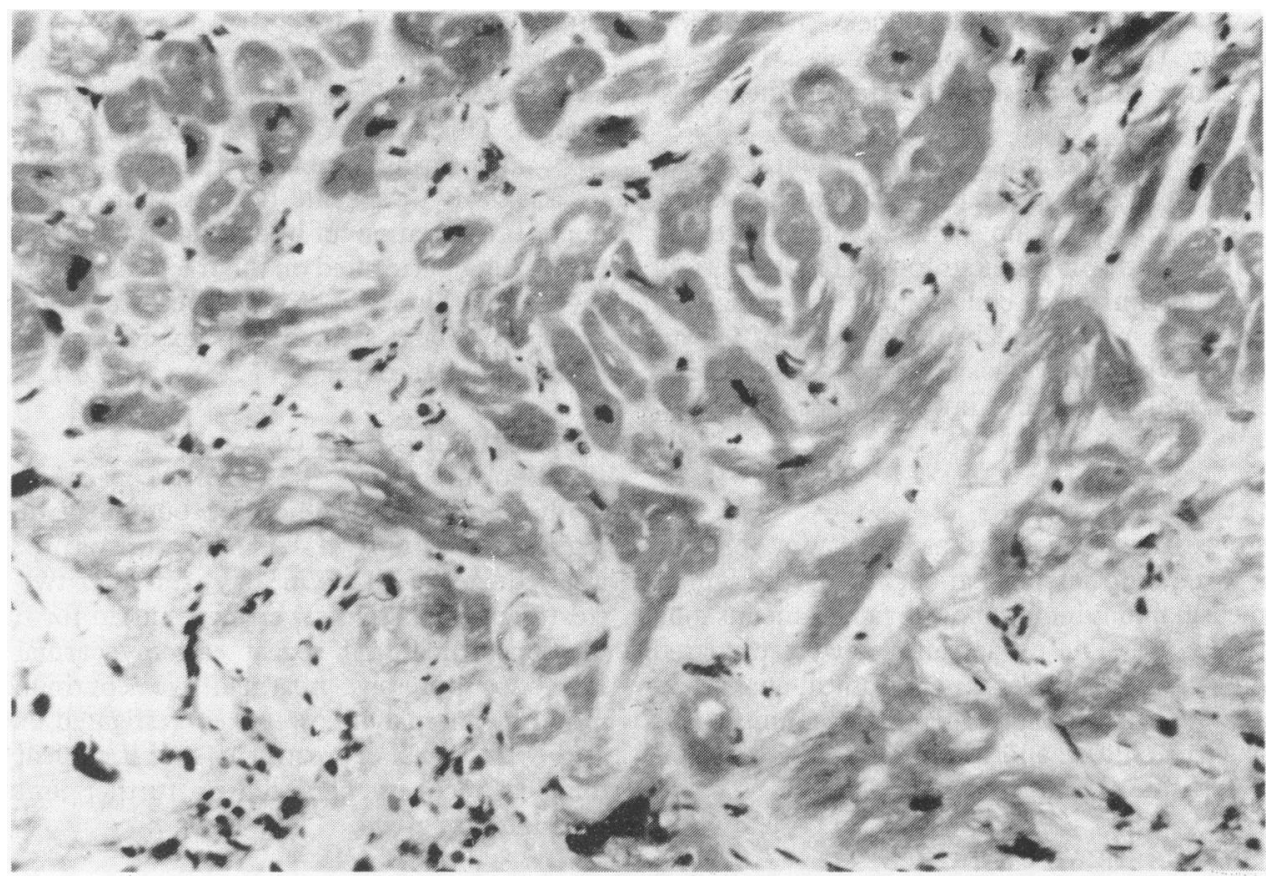

Fig. 1 Photomicrograph from a patient with myocarditis. The interstitium is widened, and chronic inflammatory cells can be seen as well as some fibrocytes. Foci of activity can be seen, for example, at the lower right hand cormer showing necrosis of myocytes. (Haematoxylin and eosin $\times 350$.)

patients. Neutralising antibody titres in excess of 320 to Coxsackie $B_{4}$ were found in four patients and to Coxsackie $B_{3}$ in one patient. Coxsackie $B$ virus specific IgM was detected in the sera of two of these patients. A rising complement fixation titre (16 to 256) against herpes simplex was detected in one patient in whom the virus was also grown from the throat swab. Coxsackie $B_{1-5}$ specific immunofluorescent staining and viral culture of the biopsy specimens were negative in all patients (Table).

\section{Histology}

Eleven patients had histological changes of acute myocarditis at presentation, and in five of these a virus infection was implicated. One patient (case 12) had a negative biopsy but positive viral serology. A follow up biopsy six months later in this patient, however, showed the features of acute myocarditis.

\section{Haemodynamic findings}

Left venticular function was severely impaired in all patients at the time of diagnosis (mean ejection fraction $26.8 \pm 3 \%$ ). Mean left ventricular end diastolic pressure for the group was $26.4 \pm 3 \mathrm{~mm} \mathrm{Hg}$, mean pulmonary artery systolic pressure $40 \pm 6 \mathrm{~mm} \mathrm{Hg}$, and mean cardiac index $2 \cdot 7 \pm 0.3 \mathrm{l} / \mathrm{min} / \mathrm{m}^{2}$.
RESPONSE TO IMMUNOSUPPRESSIVE TREATMENT Nine patients were treated with immunosuppressive drugs, eight with azathioprine and prednisolone, and one with prednisolone alone. All had histological evidence of myocarditis and three had positive viral serology. Three patients were not treated with immunosuppression at the request of the referring physicians.

Seven of the patients treated with immunosuppressive drugs showed appreciable clinical improvement after two months, with the histological features of healed myocarditis. Two patients, however (one treated with prednisolone alone), had evidence of continuing active myocarditis, and in both the histological picture was associated with the absence of clinical and haemodynamic improvement. Haemodynamic findings for the whole group improved (Fig. 2). Significant reductions in left ventricular end diastolic pressure $(26.4 \pm 3$ to $16.2 \pm 5 \mathrm{~mm} \mathrm{Hg}, \mathrm{p}<0.05)$ and pulmonary artery systolic pressure $(40 \pm 6$ to $26 \pm 4$ $\mathrm{mm} \mathrm{Hg}, \mathrm{p}<0.05$ ) were associated with increases in left ventricular ejection fraction $(26.8 \pm 3$ to $49 \pm 7 \%$, $\mathrm{p}<0.02)$ and cardiac index $(2.7 \pm 0.3$ to $3.9 \pm 0.4 \mathrm{l}$ $\left.\mathrm{min} / \mathrm{m}^{2}\right)$. Fig. 3 illustrates the haemodynamic improvement in one patient.

Of the seven patients who showed initial improve- 

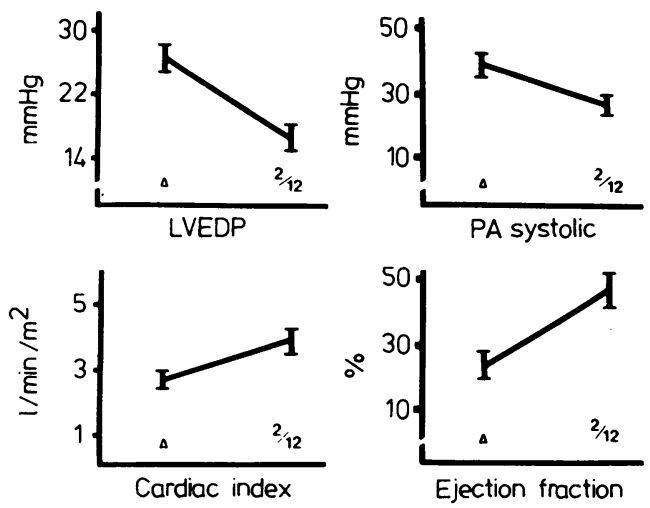

Fig. 2 Haemodynamic variables before and after two months' immunosuppressive treatment in nine patients.

LVEDP, left ventricular end diastolic pressure; $P A$, pulmonary artery; $\triangle$, at diagnosis; 2/12, after two months' treatment.
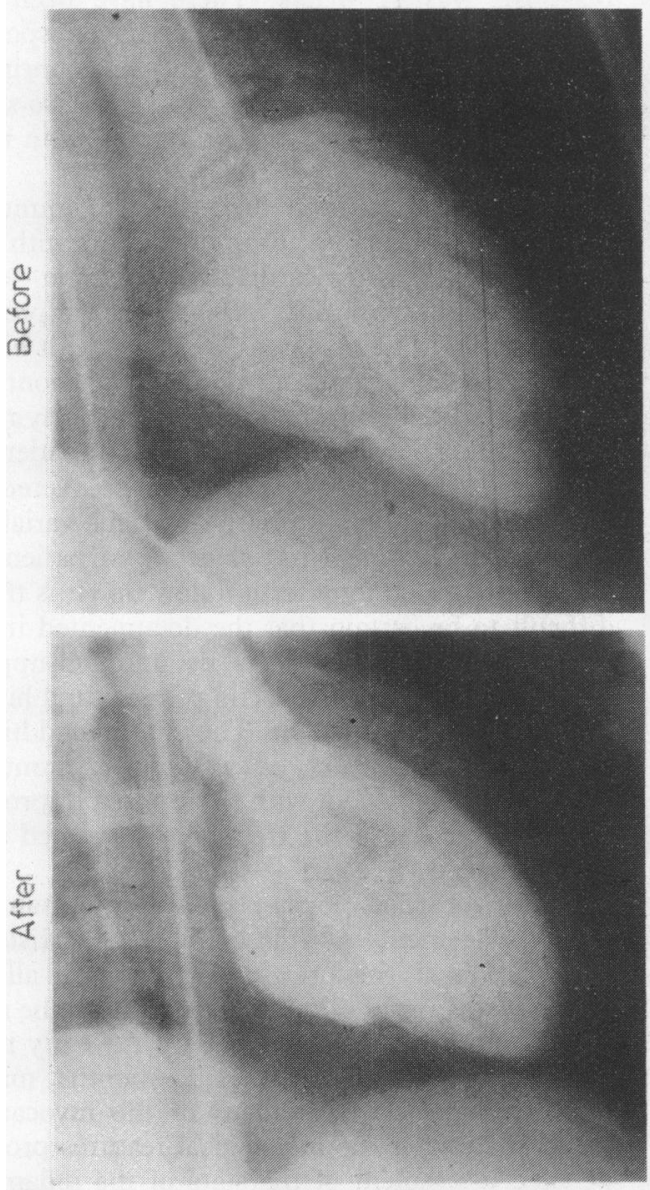

Diastole ment, four maintained this improvement on long term follow up. Immunosuppressive treatment was discontinued after six months and reinvestigation one month later showed no evidence of either haemodynamic or histological relapse. All four remained asymptomatic off medical treatment with a normal exercise capacity. The duration of symptoms and severity of left ventricular dysfunction at the time of diagnosis in these patients were not significantly different from those in the other patients.

Three patients who had shown both clinical and histological improvement at two months subsequently deteriorated. One suffered a clinical relapse one month after treatment was stopped and the repeat biopsy at the time showed reactivated myocarditis. Immunosuppressive treatment was recommenced with subsequent improvement. Two patients, whose
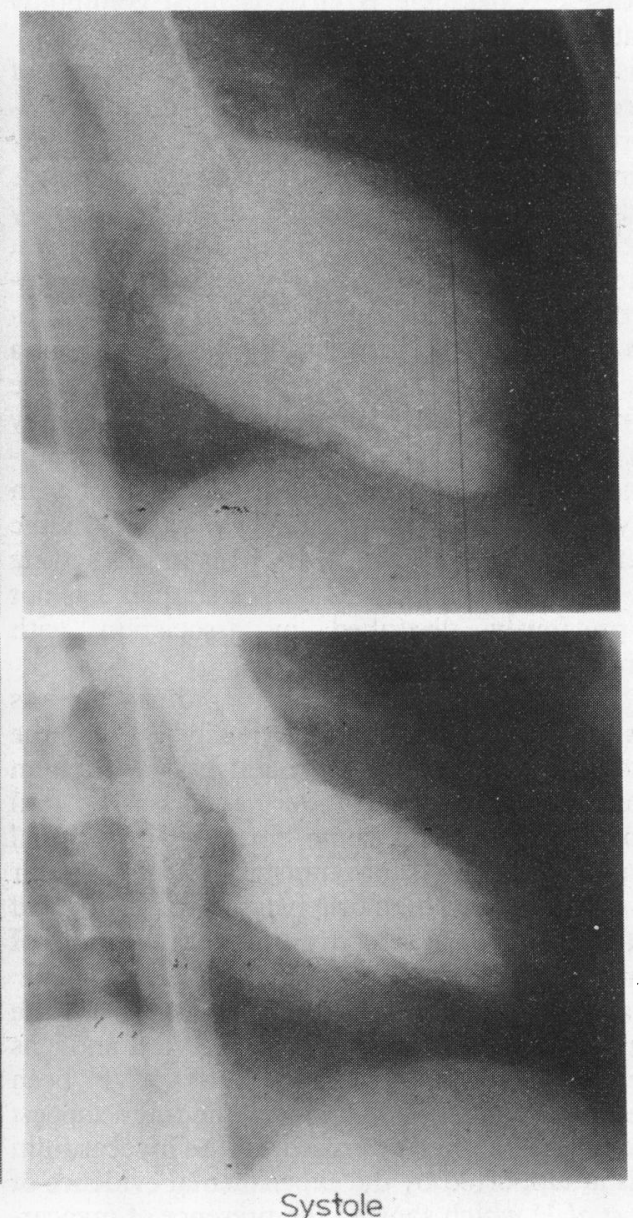

Systole

Fig. 3 Left ventricular angiogram (30 right anterior oblique) in a 15 year old girl before and two months after immunosuppressive treatment. 
biopsies at two months had shown healed myocarditis with interstitial fibrous tissue replacement, subsequently deteriorated to a clinical picture of severe dilated cardiomyopathy despite continuing immunosuppressive treatment. One of these has been referred for consideration for cardiac transplantation.

\section{Discussion}

While acute myocarditis has been accepted as a clinical entity for many years, ${ }^{7}$ its incidence, pathogenesis, and natural history have remained somewhat obscure. With the advent of endomyocardial biopsy, a definitive histological diagnosis of myocarditis is now possible during the acute stage. ${ }^{8}$ This, combined with virological studies, has allowed more detailed assessment of the condition.

Evidence has accumulated that viruses account for many cases. ${ }^{9}$ Coxsackie B virus is most commonly implicated, and Grist and Bell ${ }^{10}$ found that this group of viruses was responsible in up to $40 \%$ of cases of myocarditis and pericarditis. In our series, histologically proved myocarditis was associated with a possible virus infection in half of the patients examined. Coxsackie B virus was implicated in five patients by the presence of raised neutralising antibody titres, with the detection of Coxsackie B specific IgM providing further evidence of recent infection. Herpes simplex was diagnosed in one patient by the presence of a rising complement fixation titre and isolation of the virus from the throat. Although this infection may have been coincidental or a local reactivation, an antibody rise of such magnitude is usually seen only in primary infection or in reactivation with systemic involvement. The presence of the virus in this setting was an unexpected finding as herpes simplex has not been previously described in association with myocarditis.

The occurrence of myocarditis during virus epidemics has been described previously, ${ }^{11} 12$ and the patients in this study may represent part of such an epidemic. While up to $33 \%$ of patients with viral infections may develop some form of myocardial damage as a result, ${ }^{13}$ an unusual feature of our patients is that such a high proportion were young and presented with major haemodynamic complications of myocarditis.

It was not possible to culture the virus from the myocardial tissue nor to detect specific viral antigens in the myocardium. Similar results have been reported by Takatsu et al. ${ }^{14}$ These findings suggest that the virus is no longer present in the myocardium and this is supported by the experimental evidence of Wilson et al. ${ }^{15}$ which showed the presence of myocarditis long after the virus had cleared from the tissues. The acute histological changes may therefore reflect an immune response, and indeed there is increasing evidence that autoimmune mechanisms may be implicated in the production of myocardial necrosis after viral infections. Cytotoxic $T$ lymphocytes have been suggested as a cause of myocardial damage, ${ }^{16}$ and furthermore the studies of Fowles et al. ${ }^{17}$ indicated a defect in mononuclear cell suppressor activity in patients with congestive cardiomyopathy.

The concept of a persisting autoimmune process directed against the myocardium has suggested a role for immunosuppressive drugs in the treatment of myocarditis. Animal studies have indicated that this treatment might have a detrimental effect in the acute infective stage. 1819 Such an effect, however, is unlikely in the clinical setting. As already stated, the virus does not appear to persist in the myocardium to the time of onset of treatment, and in this study the average time between the onset of symptoms and diagnosis was 11 weeks. There have been several reports of cases of myocarditis that have responded to treatment with corticosteroids and azathioprine. ${ }^{20-22}$ The experience quoted by Mason et al. ${ }^{2}$ also supports the role of immunosuppressive treatment in myocarditis.

We have investigated the effects of immunosuppressive treatment in a group of patients with moderate to severe myocardial dysfunction due to inflammatory myocarditis. A significant improvement in myocardial function was associated with histological evidence of healing in the first two months, and this was paralleled by an improvement in symptomatic state. But between $80 \%$ and $90 \%$ of patients with clinically diagnosed myocarditis recovered completely. ${ }^{23}$ Furthermore, there was some variability of response to treatment in our group of patients, particularly those on long term follow up. It is therefore difficult to be certain that the documented improvement relates to the effects of immunosuppressive treatment rather than reflecting the natural history of the disease in each patient. The clinical and histological relapse which followed cessation of immunosuppression in one patient with subsequent improvement on reinstatement of the treatment suggested a direct beneficial effect.

Endomyocardial biopsy played an important role in the management of these patients. Histological examination at the time of presentation allowed a definitive diagnosis of acute myocarditis to be made in all but one patient. In this patient the early negative biopsy, which was positive at six months, may have reflected a focal involvement of the myocardium. ${ }^{1}$ Serial analysis of the histological features provided a detailed assessment of the state of the inflammatory process in the myocardium and so allowed more detailed monitoring of the course of the condition and the effect of immunosuppressive treatment. Serial 
biopsies in these patients also showed the presence of interstitial myocardial fibrosis, which may have important implications. It was noticeable that such fibrosis was most pronounced in those patients who despite the histological features of "healed myocarditis" progressed to a state of chronic congestive cardiac failure. Indeed, the histological examination of these patients at six months resembled the nonspecific changes of previous myocardial damage compatible with longstanding dilatation as previously described in congestive cardiomyopathy. ${ }^{24} \mathrm{~A}$ relation between preceding viral myocarditis and dilated cardiomyopathy has been suspected, and these findings indicate that the natural history of acute myocarditis may include progression to dilated cardiomyopathy. The question as to whether early intervention with immunosuppressive treatment will alter this progression has not been answered.

A need is clearly indicated for a multicentre randomised trial to establish the value of immunosuppressive treatment in histologically proved acute myocarditis and to document the natural history of this condition.

\section{References}

1 Woodruff JF. Viral myocarditis. Am F Pathol 1980; 101: 427-78.

2 Mason JW, Billingham ME, Ricci DR. Treatment of acute inflammatory myocarditis assisted by endomyocardial biopsy. Am f Cardiol 1980; 45: 1037-44.

3 New York Heart Association. Criteria Committee Cardiac Status and Prognosis. Nomenclature and criteria for diagnosis of diseases of the heart and great vessels. 7th ed. Boston: Little, Brown, 1973: 286.

4 Richardson PJ. King's endomyocardial bioptome. Lancet 1974 ; i: $660-1$.

5 Baandrup U, Olsen EGJ. Critical analysis of endomyocardial biopsies from patients suspected of having cardiomyopathy. I. Morphological and morphometric aspects. Br Heart $\mathcal{Y} 1981$; 45: 475-86.

6 El-Hargrassy MO, Banatvala JE, Coltart DJ. Coxsackie-B-virus-specific IgM responses in patients with cardiac and other diseases. Lancet 1980; ii: 1160-2.

7 Saphir O. Myocarditis-a general review with an analysis of 280 cases. Archives of Pathology (Chicago) 1941; 32: $1000-51$.

8 Sekiguchi $\mathbf{M}$, Hiroe $\mathbf{M}$, Take $\mathbf{M}$, Hirosawa $\mathrm{K}$. Clinical and histopathological profile of sarcoidosis of the heart and acute idiopathic myocarditis. Concepts through a study employing endomyocardial biopsy. II. Myocarditis. Fpn Circ J 1980; 44: 264-73.

9 Lerner AM. Coxsackievirus myocardiopathy. F Infect Dis 1969; 120: 496-9.
10 Grist NR, Bell EJ. A six year study of Coxsackievirus B infections in heart disease. $f$ Hyg (Camb) 1974; 73: 16572.

11 Public Health Laboratory Service. Coxsackie $B_{5}$ virus infection during 1965. A report to the director of the public health laboratory service from various laboratories in the United Kingdom. Br Med f 1967; iv: 575-7.

12 Kirbrick S, Benirschke K. Acute aseptic myocarditis and meningoencephalitis in the newborn child infected with Coxsackie virus group B, type 3. N Engl f Med 1956; 255: 883-9.

13 Helin M, Savola J, Lapinleimu K. Cardiac manifestations during a Coxsackie $B_{5}$ epidemic. $B r M e d ~ F ~ 1968$; iii: 97-9.

14 Takatsu T, Kitamura Y, Morita H, Deguchi M, Imamura I, Kawamura $K$. Viral myocarditis and cardiomyopathy. In: Sekiguchi M, Olsen EGJ, eds. Cardiomyopathy - clinical, pathological and theoretical aspects. Tokyo: University of Tokyo Press, 1980: 341-63.

15 Wilson FM, Miranda QR, Chason JL, Lerner AM. Residual pathologic changes following murine Coxsackie A and B myocarditis. Am $\mathcal{F}$ Pathol 1969; 55: 253-65.

16 Wong CY, Woodruff JJ, Woodruff JF. Generation of cytotoxic $T$ lymphocytes during Coxsackie $B_{3}$ infection. 2. Characterization of effector cells and demonstration cytotoxicity against used infected myofibers. $f$ Immunol 1977; 118: 1165-9.

17 Fowles RE, Bieber CP, Stinson EB. Defective in-vitro suppressor cell function in idiopathic congestive cardiomyopathy. Circulation 1979; 59: 483-91.

18 Rytel MW, Kilbourne ED. Differing susceptibility of adolescent and adult mice to non-lethal infection with Coxsackievirus $B_{3}$. Proc Soc Exp Biol Med 1971; 137: 443-8.

19 Kilbourne ED, Wilson CB, Perrier D. The induction of gross myocardial lesions by Coxsackie (pleurodynia) virus and cortisone. 7 Clin Invest 1956; 35: 362-70.

20 Voigt GC. Steroid therapy in viral myocarditis [Letter]. Am Heart f 1968; 75: 575-6.

21 Fenoglio JJ, Ursell PC, Kellogg CF, Drusin RE, Weiss MB. Diagnosis and classification of myocarditis by endomyocardial biopsy. $N$ Engl f Med 1983; 308: 12-8.

22 O'Connell JB, Robinson JA, Henkin RE, Gunnar RM. Immunosuppressive therapy in patients with congestive cardiomyopathy and myocardial uptake of gallium-67. Circulation 1981; 64: 780-6.

23 Anonymous. Acute myocarditis and its sequelae [Editorial]. Br Med F 1972; iii: 783-4.

24 Baandrup U, Florio RA, Rehahn M, Richardson PJ, Olsen EGJ. Critical analysis of endomyocardial biopsies from patients suspected of having cardiomyopathy. II: Comparison of histology and clinical/haemodynamic information. Br Heart $\mathcal{F}$ 1981; 45: 487-93.

Requests for reprints to Dr P J Richardson, Cardiac Department, King's College Hospital, Denmark Hill, London SE5 9RS. 